Supporting Information

\title{
Peptide-Cleaving Catalyst Selective for Peptide Deformylase
}

Pil Seok Chae, Myoung-soon Kim, Chul-Seung Jeung, Seong Du Lee, Hwangseo Park, Sangyoub Lee, and Junghun Suh*

Department of Chemistry, Seoul National University, Seoul 151-747, Korea

$=$
$=$

Contents

(1) Structures of carboxylic acids, amines, aldehydes, and isocyanides used for construction of members of the library

(2) Experimental procedures for synthesis of cyclen-containing carboxylic acids (A19-A22)

(3) Experimental procedures for synthesis of cyclen-containing amines (B19-B21)

(4) Experimental procedures for construction of the library

(5) Synthesis of Co(III)1

(6) Details of theoretical analysis

(7) List of proteins tested with Co(III) 1 
(1) Structures of carboxylic acids, amines, aldehydes, and isocyanides used for construction of members of the library<smiles>COc1ccc([C@H](O)C(=O)O)cc1OC</smiles>

A1

A2<smiles>O=C(NC(C(=O)O)c1ccccc1)c1cc([N+](=O)[O-])cc([N+](=O)[O-])c1</smiles>

A4<smiles>CC(=O)SC[C@H](C)C(=O)N1CCC[C@]1(C)C(=O)O</smiles>

A5

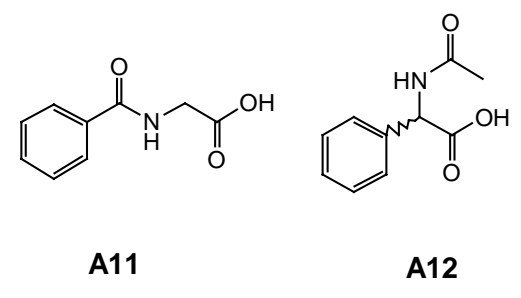

A10

A9<smiles>Cc1ccc(C(=O)O)cc1[N+](=O)[O-]</smiles>

A13

A14<smiles>CC(O)C(NC(=O)c1ccccc1)C(=O)OCc1ccccc1</smiles><smiles>CC(=O)N1CCCC1C(=O)O</smiles>

A17

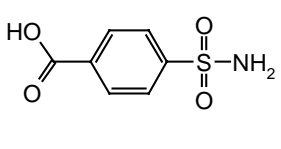

A18

A15

A16

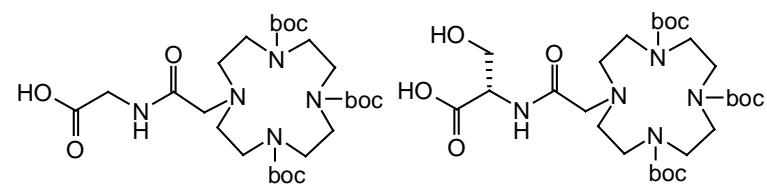<smiles>CC(O)[C@H](NC(C(=O)O)C1CCN2CCN(C)CCN(CC1)CC2)C(=O)O</smiles>

A19

A20

A21

A22 


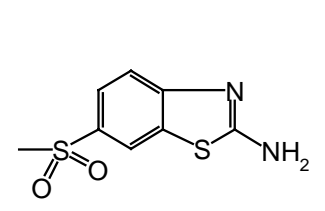

B1<smiles>[Te]</smiles>

B2<smiles>NC(CO)c1ccccc1</smiles>

B3<smiles>CC(C)(C)OC(=O)NCc1cccc(CN)c1</smiles><smiles>NC(=O)c1ccc(N)cc1</smiles><smiles>CC(=O)ONCc1ccc(N)cc1</smiles><smiles>Nc1ccc(Cc2ccc(N3C(=O)C4C5C=CC(C5)C4C3=O)cc2)cc1</smiles><smiles>Nc1ncc(S(=O)(=O)c2ccc([N+](=O)[O-])cc2)s1</smiles><smiles>Nc1cc([N+](=O)[O-])cc([N+](=O)[O-])c1</smiles>

B8<smiles>Nc1ccc(NC(=O)Nc2ccccc2)cc1</smiles>

B10<smiles>NCCCN1CCCC1=O</smiles>
B11<smiles>CC(C)C(N)CONCc1ccc(CN)cc1</smiles><smiles>CC(C)(C)OC(=O)C(N)CCCCNC(=O)OCc1ccccc1</smiles><smiles>COC(=O)C(N)CCCCNC(=O)OCc1ccccc1</smiles><smiles>CCOC(=O)C(N)Cc1ccc(O)cc1</smiles>

B12<smiles>[R6]N1CCN(CCCN)CCN(C(=O)O)CCN(C(=O)O)CC1</smiles>

B19<smiles>NCC(=O)NCCCN1CCN(C(=O)O)CCN(C(=O)O)CCN(C(=O)O)CC1</smiles>

B20<smiles>NCCC(=O)NCCCN1CCN(C(=O)O)CCN(C(=O)O)CCN(C(=O)O)CC1</smiles>

B21 
<smiles>CC(=O)n1cc(C=O)c2ccccc21</smiles>

C1<smiles>Cn1cc(C=O)c2ccccc21</smiles>

C2<smiles>COc1cc(C=O)cc(I)c1O</smiles>

C3<smiles>CC(=O)OCc1ccc(C=O)o1</smiles>

C4<smiles>O=CC1CCCN1S(=O)(=O)c1ccccc1</smiles><smiles>CN(C)c1ccc(C=O)cc1</smiles>

C5<smiles>O=Cc1ccc(OCCO)cc1</smiles>

C8<smiles>COc1cc(/C=C/C=O)ccc1O</smiles>

c9

C10<smiles>Cn1ccnc1C=O</smiles>

C11<smiles>COC(=O)c1ccc(C=O)cc1</smiles>

C12<smiles>CC(C)(C)c1cccc2ccccc12</smiles>

C13 C14<smiles>O=Cc1ccc2ccccc2c1</smiles><smiles>O=Cc1ccc(Oc2ccccc2)cc1</smiles><smiles>COc1cc(C=O)cc(I)c1O</smiles>

C15 C16 C17<smiles>CC(C)(C)CC(C)(C)C</smiles>

D1<smiles></smiles>

D2<smiles>CC(C)N=[N+]=[N-]</smiles>

D3<smiles>N#CC1CCCCC1</smiles>

D4<smiles>CC(C)(C)[NH3+]</smiles>

D5 
(2) Experimental procedures for synthesis of cyclen-containing carboxylic acids (A19-A22)

[4,7,10-Tris(t-butoxycarbonyl)-1,4,7,10-tetraazacyclododec-1-yl]-acetic acid (A19) was synthesized according to the literature (Jeon, J. W.; Son, S. J.; Yoo, C. E.; Hong, I. S.; Song, J. B.; Suh, J. Org. Lett. 2002, 4, 4155-4158).

\section{Scheme S1}

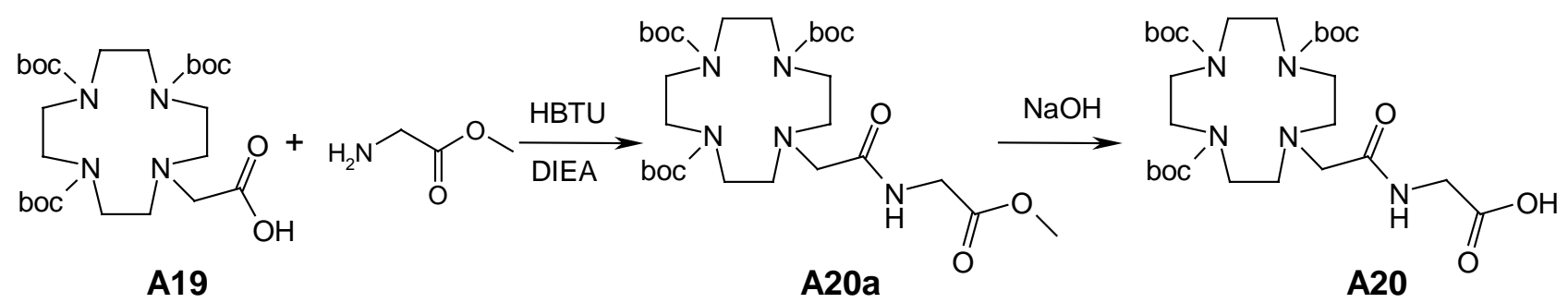

$N$-\{[4,7,10-Tris(t-butoxycarbonyl)-1,4,7,10-tetraazacyclododecan-1-yl]acetyl $\}$ glycine $\quad$ (A20) was synthesized according to Scheme S1. To the stirred solution of A19 (2.5 g, $4.7 \mathrm{mmol})$ in $\mathrm{CH}_{3} \mathrm{CN}(100$ $\mathrm{mL})$ were added the $\mathrm{HCl}$ salt of glycine methyl ester $(0.7 \mathrm{~g}, 4.8 \mathrm{mmol})$ and diisopropylethylamine (DIEA) $(2.5 \mathrm{~mL}, 14 \mathrm{mmol})$. To the reaction mixture was added $O$-benzotriazol-1-yl- $N, N, N^{\prime}, N^{\prime}-$ tetramethyluroniumhexafluoro phosphate (HBTU) $(1.8 \mathrm{~g}, 4.8 \mathrm{mmol})$ and the mixture was stirred for 1 hour. The solution was evaporated and the residue was dissolved in EtOAc (100 mL). The EtOAc solution was washed with $5 \%$ aq. citric acid $(50 \mathrm{~mL}), 5 \%$ aq. $\mathrm{Na}_{2} \mathrm{CO}_{3}(50 \mathrm{~mL})$, and brine $(50 \mathrm{~mL})$, and then dried over $\mathrm{Na}_{2} \mathrm{SO}_{4}$. The solvent was evaporated and column chromatography afforded $N$ $\{[4,7,10$-tris ( $t$-butoxycarbonyl)-1,4,7,10-tetraazacyclododecan-1-yl]acetyl $\}$ glycine methyl ester (A20a) as a colorless amorphous solid. $R_{f} 0.1$ (EtOAc/hexane $\left.2: 1\right)$. To the solution of A20a (2.2 $\left.\mathrm{g}, 3.7 \mathrm{mmol}\right)$ in $\mathrm{MeOH}(100 \mathrm{~mL})$ was added aq. $\mathrm{NaOH}(1 \mathrm{M}, 50 \mathrm{~mL})$. The reaction mixture was stirred for 2 hours. The solvent was evaporated, the residue was dissolved in $10 \%$ aq. citric acid, and pH was adjusted to 3 . After the solution was extracted with EtOAc $(100 \mathrm{~mL} \times 3)$ and the organic layer was washed with brine $(50 \mathrm{~mL})$, dried over $\mathrm{Na}_{2} \mathrm{SO}_{4}$, and evaporated, A20 was obtained as a white solid. ${ }^{1} \mathrm{H}$ NMR $(300 \mathrm{MHz}$, $\left.\mathrm{CDCl}_{3}\right): \delta 9.23(\mathrm{br}, 1 \mathrm{H}), 7.50(\mathrm{br}, 1 \mathrm{H}), 4.0(\mathrm{~d}, 2 \mathrm{H}), 3.7-2.7(\mathrm{br}, 18 \mathrm{H}), 1.7-1.3(\mathrm{~m}, 27 \mathrm{H})$; MS (MALDITOF) $m / z 588.70(\mathrm{M}+\mathrm{H})^{+}$, calcd for $\mathrm{C}_{27} \mathrm{H}_{50} \mathrm{~N}_{5} \mathrm{O}_{9} 588.73$. 
Compounds A21 and A22 were synthesized according to the method employed for A20 by using the respective amino acid methyl esters. $N$-\{[4,7,10-Tris(t-butoxycarbonyl)-1,4,7,10-tetraazacyclododecan-1-yl]acetyl\}-L-serine (A21); ${ }^{1} \mathrm{H}$ NMR $\left(300 \mathrm{MHz}, \mathrm{CDCl}_{3}\right): \delta 8.90(\mathrm{br}, 1 \mathrm{H}), 7.97$ (br, $\left.1 \mathrm{H}\right), 4.58(\mathrm{br}$, 1H), 4.2-2.6 (br, 21H), 1.8-1.2 (m, 27H); MS (MALDI-TOF) $m / z 618.81(\mathrm{M}+\mathrm{H})^{+}$, calcd for $\mathrm{C}_{28} \mathrm{H}_{52} \mathrm{~N}_{5} \mathrm{O}_{10}$ 618.75. $N$ - $\{[4,7,10$-Tris( $t$-butoxycarbonyl)-1,4,7,10-tetraazacyclododecan-1-yl $]$ acetyl $\}$-Lthreonine (A22); ${ }^{1} \mathrm{H}$ NMR (300 MHz, $\left.\mathrm{CDCl}_{3}\right): \delta 7.64(\mathrm{br}, 2 \mathrm{H}), 4.56(\mathrm{~d}, 1 \mathrm{H}), 4.42(\mathrm{~m}, 1 \mathrm{H}), 3.8-2.8(\mathrm{br}$, 19H), 1.7-1.3 (m, 27H), 1.3-1.1 (m, 3H); MS (MALDI-TOF) $m / z 632.79(\mathrm{M}+\mathrm{H})^{+}$, calcd for $\mathrm{C}_{29} \mathrm{H}_{54} \mathrm{~N}_{5} \mathrm{O}_{10} 632.78$. 


\section{(3) Experimental procedures for synthesis of cyclen-containing amines (B19-B21)}

\section{Scheme S2}
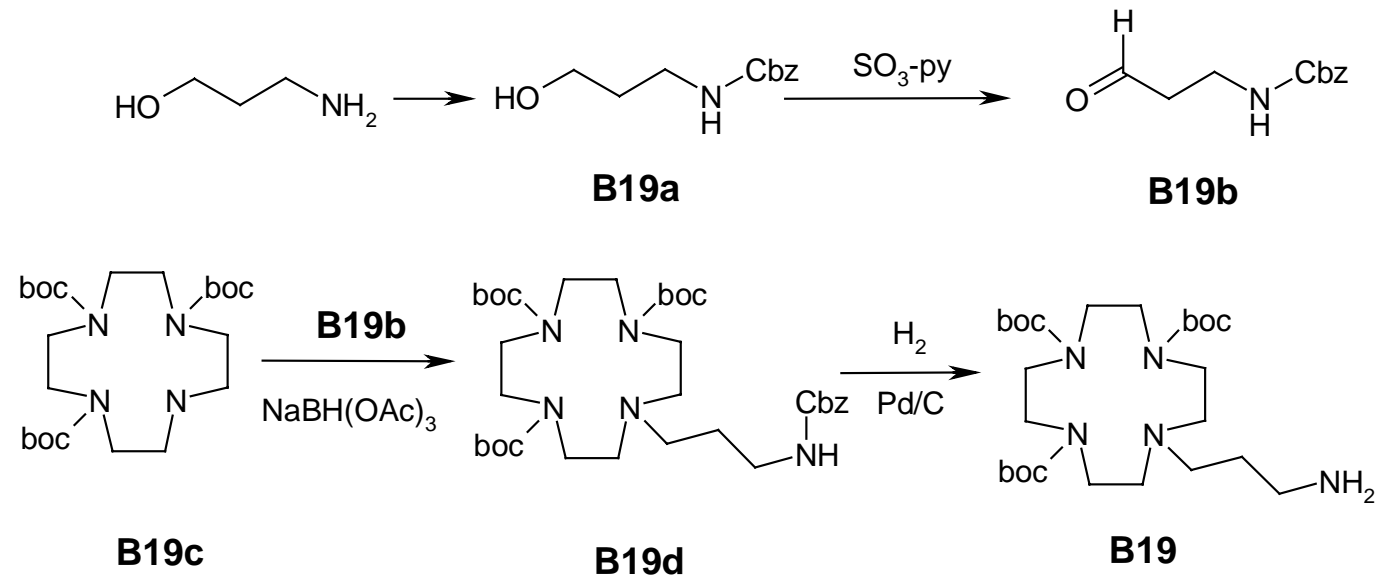

1-Aminopropyl-4,7,10-tri(t-butoxycarbonyl)-1,4,7,10-tetraazacyclododecane (B19) was synthesized according to Scheme S2. To the solution of 3-amino-1-propanol $(10 \mathrm{~mL}, 130 \mathrm{mmol})$ in $\mathrm{CHCl}_{3}(100$ $\mathrm{mL})$ was added triethylamine (TEA) $(19 \mathrm{~mL}, 130 \mathrm{mmol})$. To the stirred solution, benzyl chloroformate (19 $\mathrm{mL}, 130 \mathrm{mmol})$ was added dropwise. The reaction mixture was stirred for 3 hours, then washed with $5 \%$ aq. citric acid $(50 \mathrm{~mL} \times 3)$ and brine $(50 \mathrm{~mL})$, and dried over $\mathrm{Na}_{2} \mathrm{SO}_{4}$. The solvent was evaporated and column chromatography afforded 3-[N-(benzoxycarbonyl)-amino]-1-propanol (B19a) as a colorless oil. $R_{f} 0.3\left(\right.$ EtOAc/hexane 2:1); ${ }^{1} \mathrm{H}$ NMR $\left(300 \mathrm{MHz}, \mathrm{CDCl}_{3}\right): \delta 7.29(\mathrm{~m}, 5 \mathrm{H}), 5.69(\mathrm{~m}$, 1H), $5.03(\mathrm{~s}, 2 \mathrm{H}), 3.79(\mathrm{~s}, 1 \mathrm{H}), 3.58(\mathrm{~m}, 2 \mathrm{H}), 3.23(\mathrm{~m}, 2 \mathrm{H}), 1.65(\mathrm{~m}, 2 \mathrm{H})$. To the solution of B19a $(14 \mathrm{~g}$, $69 \mathrm{mmol})$ in DMSO/methylene chloride (MC) $(70 \mathrm{~mL} / 70 \mathrm{~mL})$ cooled to $0 \square$ was added TEA (48 mL, $350 \mathrm{mmol})$. To the stirred solution, sulfur trioxide-pyridine complex (33 g, $210 \mathrm{mmol})$ was added. The reaction mixture was stirred for 1 hour in an ice bath. After addition of $\mathrm{MC}(100 \mathrm{~mL})$, the reaction mixture was washed with $10 \%$ aq. $\mathrm{CuSO}_{4}(100 \mathrm{~mL} \times 2), 5 \%$ aq. citric acid $(100 \mathrm{~mL})$, and brine $(100$ $\mathrm{mL}$ ). The solvent was evaporated and column chromatography afforded 3-[N-(benzoxy-carbonyl)amino]-1-propanal (B19b) as a colorless oil. $R_{f} 0.2$ (EtOAc/hexane 1:2); ${ }^{1} \mathrm{H}$ NMR $\left(300 \mathrm{MHz}, \mathrm{CDCl}_{3}\right): \delta$ $9.82(\mathrm{~s}, 1 \mathrm{H}), 7.44(\mathrm{~m}, 5 \mathrm{H}), 5.75(\mathrm{~m}, 1 \mathrm{H}), 5.19(\mathrm{~s}, 2 \mathrm{H}), 3.55(\mathrm{~m}, 2 \mathrm{H}), 2.75(\mathrm{~m}, 2 \mathrm{H})$. 
To the solution of B19c (Abdel-Magid, A. F.; Maryanoff, C. A.; Carson, K. G. Tet. Lett. 1990, 31, 5595-5598) (23 g, $48 \mathrm{mmol})$ in tetrahydrofuran (THF) (150 mL) were added the solution of B19b (10 g, $48 \mathrm{mmol})$ in $\mathrm{THF}(100 \mathrm{~mL})$ and $\mathrm{NaBH}(\mathrm{OAc})_{3}(30 \mathrm{~g}, 140 \mathrm{mmol})$. The reaction mixture was stirred for 1 hour. THF was evaporated and the reaction mixture was mixed with $50 \mathrm{~mL}$ saturated $\mathrm{Na}_{2} \mathrm{CO}_{3}$ and extracted with EtOAc $(50 \mathrm{~mL} \times 2)$. The collected organic phase was washed with brine, dried over $\mathrm{Na}_{2} \mathrm{SO}_{4}$, and concentrated. Column chromatography on silica gel (EtOAc/hexane 1:1) afforded 1-(Nbenzoxycarbonyl-aminopropyl)-4,7,10-tri(t-butoxycarbonyl)-1,4,7,10-tetraazacyclododecane (B19d). $\mathrm{R}_{f}$ 0.5 (EtOAc/hexane 2:1); ${ }^{1} \mathrm{H}$ NMR $\left(\mathrm{CDCl}_{3}, 300 \mathrm{MHz}\right): \delta 7.32(\mathrm{~m}, 5 \mathrm{H}), 5.09(\mathrm{~s}, 2 \mathrm{H}), 3.56-3.16$ (br, 14H), $2.58(\mathrm{br}, 6 \mathrm{H}), 1.66(\mathrm{~m}, 2 \mathrm{H}), 1.44(\mathrm{~m}, 27 \mathrm{H})$. A suspension of B19d (10 g, $15 \mathrm{mmol})$ and $10 \%$ $\mathrm{Pd} / \mathrm{C}(5 \mathrm{~g})$ in $100 \mathrm{~mL}$ of EtOH was stirred under 1 atm of $\mathrm{H}_{2}$ for 24 hours. The catalyst was filtered off on Celite and the solvent was evaporated to afford B19 as a colorless oil. ${ }^{1} \mathrm{H} \mathrm{NMR}\left(300 \mathrm{MHz}, \mathrm{CDCl}_{3}\right)$ :

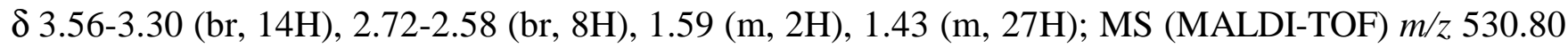
$(\mathrm{M}+\mathrm{H})^{+}$, calcd for $\mathrm{C}_{26} \mathrm{H}_{52} \mathrm{~N}_{5} \mathrm{O}_{6} 530.74$.

\section{Scheme S3}
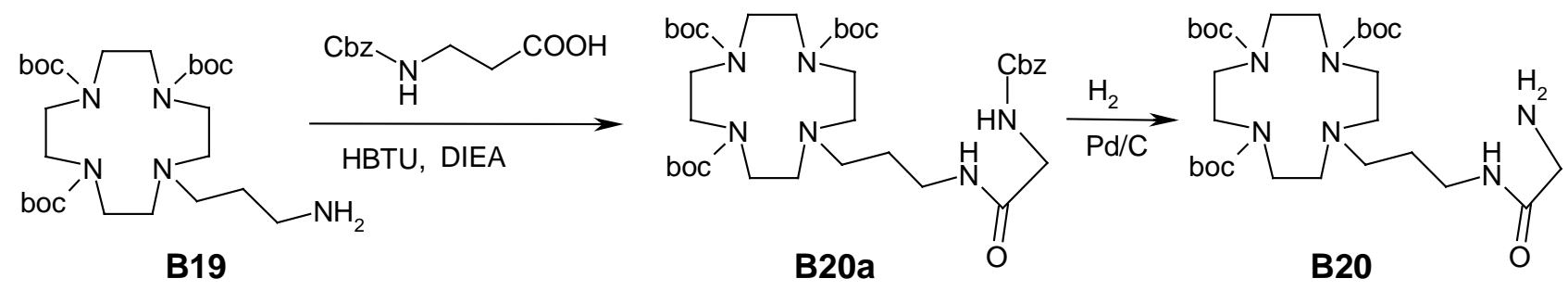

Tri-t-butyl 10-[3-(glycylamino)propyl]-1,4,7,10-tetraazacyclododecane-1,4,7-tricarboxylate

(B20) was synthesized according to Scheme S3. To the stirred solution of B19 (3.3 g, $6.2 \mathrm{mmol})$ in $\mathrm{CH}_{3} \mathrm{CN}$ (100 mL) were added $N$ - $\alpha$-Cbz-glycine $(1.3 \mathrm{~g}, 6.2 \mathrm{mmol})$ and DIEA (3.2 mL, $18 \mathrm{mmol})$. To the reaction mixture was added HBTU $(2.3 \mathrm{~g}, 6.2 \mathrm{mmol})$ and the mixture was stirred for 1 hour. The solution was evaporated and the residue was dissolved in EtOAc $(100 \mathrm{~mL})$. The EtOAc solution was washed with $5 \%$ aq. citric acid $(50 \mathrm{~mL}), 5 \%$ aq. $\mathrm{Na}_{2} \mathrm{CO}_{3}(50 \mathrm{~mL})$, and brine $(50 \mathrm{~mL})$, and dried over $\mathrm{Na}_{2} \mathrm{SO}_{4}$. The solvent was evaporated and column chromatography afforded tri-t-butyl 10-[3-(\{N-[(benzyloxy)- 
carbon-yl]glycyl \}amino)propyl]-1,4,7,10-tetraazacyclododecane-1,4,7-tricarboxylate (B20a) as a colorless oil. $R_{f} 0.2$ (EtOAc); ${ }^{1} \mathrm{H}$ NMR (300 MHz, $\left.\mathrm{CDCl}_{3}\right): \delta 7.30-7.25(\mathrm{~m}, 5 \mathrm{H}), 7.04$ (br, $\left.1 \mathrm{H}\right), 5.92(\mathrm{br}$, 1H), $5.11(\mathrm{~s}, 2 \mathrm{H}), 3.95-3.93(\mathrm{~d}, 2 \mathrm{H}), 3.54-3.26(\mathrm{br}, 14 \mathrm{H}), 2.70-2.40(\mathrm{br}, 4 \mathrm{H}), 2.0-1.6$ (br, 4H), 1.51$1.21(\mathrm{~m}, 27 \mathrm{H})$. A suspension of B20a $(2.4 \mathrm{~g}, 3.4 \mathrm{mmol})$ and $1.0 \mathrm{~g}$ of $10 \% \mathrm{Pd} / \mathrm{C}$ in $80 \mathrm{~mL}$ of EtOH was stirred under 1 atm of $\mathrm{H}_{2}$ for $24 \mathrm{hr}$. The catalyst was filtered off on Celite and the solvent was evaporated to afford B20 as an amorphous solid. ${ }^{1} \mathrm{H}$ NMR $\left(300 \mathrm{MHz}, \mathrm{CDCl}_{3}\right): \delta 7.47(\mathrm{br}, 1 \mathrm{H}), 3.60-$ $3.20(16 \mathrm{H}), 2.70-2.50(6 \mathrm{H}), 2.0-1.6(\mathrm{br}, 4 \mathrm{H}), 1.50-1.20(\mathrm{~m}, 27 \mathrm{H}) ;$ MS (MALDI-TOF) $\mathrm{m} / z .587 .87$ $(\mathrm{M}+\mathrm{H})^{+}$, calcd for $\mathrm{C}_{28} \mathrm{H}_{55} \mathrm{~N}_{6} \mathrm{O}_{7} 587.79$.

Tri-t-butyl 10-[3-( $\beta$-alanylamino)propyl]-1,4,7,10-tetraazacyclododecane-1,4,7-tricarboxylate (B21) was synthesized according to the method employed for the preparation of B20 by using $N-\alpha-\mathrm{Cbz}-\beta-$ alanine instead of $N$ - $\alpha$-Cbz-glycine. ${ }^{1} \mathrm{H}$ NMR (300 MHz, $\mathrm{CDCl}_{3}$ ): $\delta$ 3.54-3.25 (br, 14H), $3.02-2.98(\mathrm{t}$, 1H), 2.80-2.50 (br, 6H), 2.38-2.34 (m, 2H), 2.00-1.50 (br, 5H), 1.50-1.20 (m, 27H); MS (MALDI-TOF) $m / z, 601.93(\mathrm{M}+\mathrm{H})^{+}$, calcd for $\mathrm{C}_{29} \mathrm{H}_{57} \mathrm{~N}_{6} \mathrm{O}_{7} 601.82$. 


\section{(4) Experimental procedures for construction of the library}

Methanolic solutions $(0.1 \mathrm{M})$ were made for each carboxylic acid, amine, aldehyde, or isocyanide component of the Ugi condensation reaction and were used for preparation of the library. When a Cyccontaining carboxylic acid was used, one of A19-A22 (180 $\mu \mathrm{L}), 9$ amines (B1-B9 or B10-B18) $(20 \mu \mathrm{L}$ each), and an aldehyde (one of $\mathrm{C} 1-\mathrm{C} 12)(180 \mu \mathrm{L})$ were mixed together. Ten minutes later, an isocyanide component (one of D1-D5) $(180 \mu \mathrm{L}$ ) was added to the mixture. The resulting solution was shaken at room temperature for 24 hour and then was evaporated. The residue was treated with $50 \%$ trifluoroacetic acid (TFA) in $\mathrm{MC}(50 \mu \mathrm{L})$ for 5 hour and ether $(1 \mathrm{~mL})$ was added to the TFA solution. The precipitates were separated by centrifugation, washed with ether several times, and dissolved in MeOH $(200 \mu \mathrm{L})$. When a Cyc-containing amine was used, one of B19-B21 (180 $\mu \mathrm{L}), 9$ carboxylic acids (A1-A9 or A10-A18) $(20 \mu \mathrm{L}$ each), and an aldehyde (one of $\mathrm{C} 1-\mathrm{C} 12)(180 \mu \mathrm{L})$ were mixed together and were subject to the Ugi condensation reaction as described above. A small portion of the condensation product mixture was then converted to $\mathrm{Co}$ (III) complexes by adding $\mathrm{CoCl}_{2}$ in a 1:1 molar ratio with regard to the initially added amount of Cyc followed by air-oxidation of the complexed Co(II) ion according to literature (Castillo-Blum, S. E.; Sosa-Torres, M. E. Polyhedron 1995, 14, 223-229). 


\section{(5) Synthesis of Co(III)1}

Scheme S4

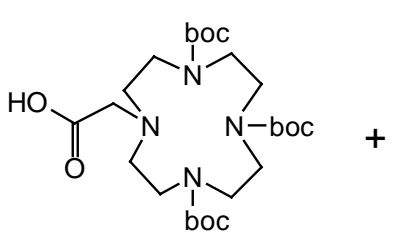

A19<smiles>CC(C)(C)OC(=O)NCc1ccc(CN)cc1</smiles>

B12

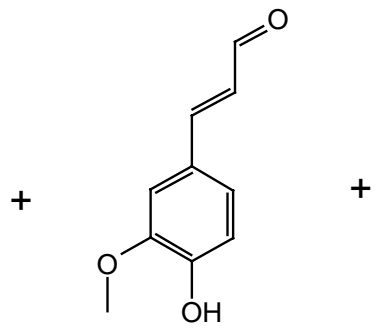

C9<smiles>N#CC1CCCCC1</smiles>

D2

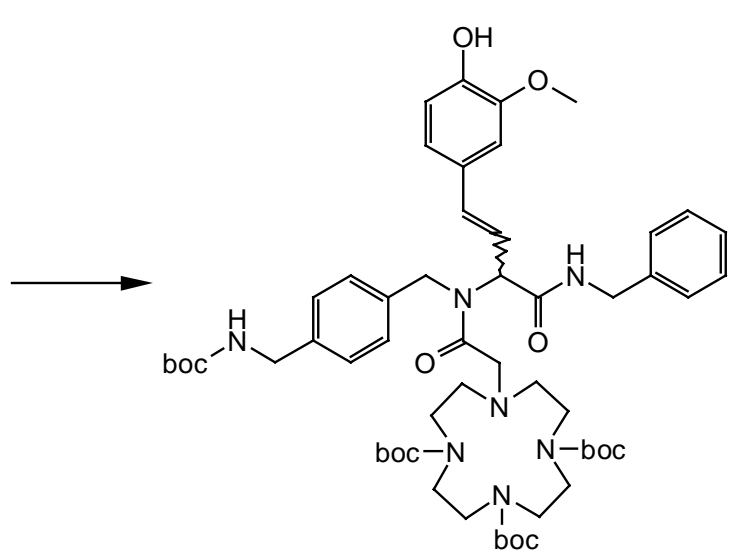

1 a

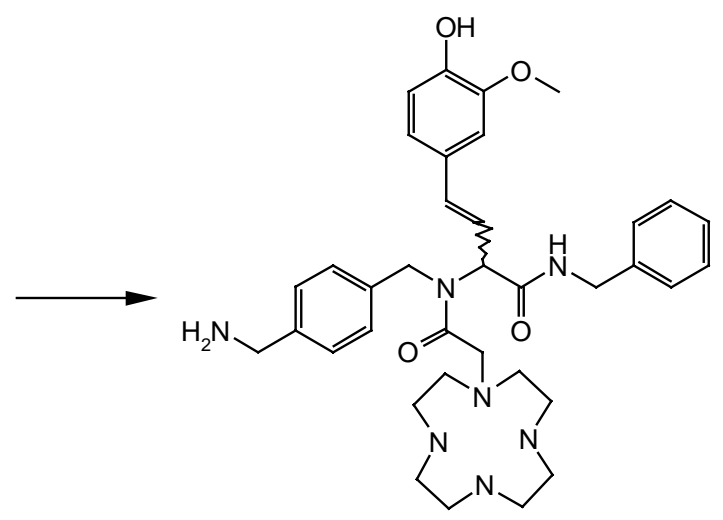

1

As indicated in Scheme S4, A19 (0.36 g, $0.68 \mathrm{mmol}), \mathrm{B} 12(0.24 \mathrm{~g}, 0.68 \mathrm{mmol}), \mathrm{C} 9(0.18 \mathrm{~g}, 0.68$ mmol) were dissolved in $\mathrm{MeOH}(25 \mathrm{~mL})$. Ten minutes later, $\mathrm{D} 2(83 \mu \mathrm{L}, 0.68 \mathrm{mmol})$ was added to the reaction mixture. The resulting solution was stirred at room temperature for $48 \mathrm{~h}$. The solution was evaporated and the residue was dissolved in EtOAc $(25 \mathrm{~mL})$. The EtOAc solution was washed with 5\% aq. citric acid $(25 \mathrm{~mL}), 5 \%$ aq. $\mathrm{Na}_{2} \mathrm{CO}_{3}(25 \mathrm{~mL})$, and brine $(25 \mathrm{~mL})$, and then dried over $\mathrm{Na}_{2} \mathrm{SO}_{4}$. The solvent was evaporated and column chromatography afforded racemic mixture of 10-(\{[(E)-1benzylcarbamoyl-3-(4-hydroxy-3-methoxy-phenyl)-allyl]-[4-(t-butoxy-carbonylamino-methyl)-benzyl]carbamoyl $\}$-methyl)-1,4,7,10-tetraazacyclododecane-1,4,7-tricarboxylic acid tri-t-butyl ester (1a) as a white solid. $R_{f} 0.2(\mathrm{MC} / \mathrm{MeOH} 20: 1) .{ }^{1} \mathrm{H}$ NMR (300 MHz, $\left.\mathrm{CDCl}_{3}\right): \delta 8.24(\mathrm{br}, 1 \mathrm{H}), 7.33-7.01(\mathrm{~m}, 9 \mathrm{H})$, 6.83-6.74 (m, 3H), $6.67(\mathrm{dd}, 1 \mathrm{H}), 6.47(\mathrm{dd}, 1 \mathrm{H}), 5.22(\mathrm{~s}, 1 \mathrm{H}), 4.9$ (br, 1H), 4.40-4.76 (m, 6H), 4.30$4.20(\mathrm{~d}, 2 \mathrm{H}), 3.73$ (s, 3H), 3.68-3.46 (s, 12H), 2.79 (br, 4H), 1.43-1.25 (s, 36H); MS (MALDI-TOF) 
$m / z$ 1045.37 $(\mathrm{M}+\mathrm{H})^{+}$, calcd for $\mathrm{C}_{39} \mathrm{H}_{54} \mathrm{~N}_{8} \mathrm{O}_{6}$ 1045.31. To the solution of 1a (1.0 g, $\left.1.0 \mathrm{mmol}\right)$ in $\mathrm{MC}$ (10 $\mathrm{mL})$ was added TFA $(10 \mathrm{~mL})$. The reaction mixture was stirred for 5 hours. After removal of the solvent by evaporation, $30 \mathrm{~mL}$ of ether was added and the resulting precipitate was washed with ether and dried in vacuo to produce the TFA salt of 1 as a white powder. ${ }^{1} \mathrm{H}$ NMR $\left(300 \mathrm{MHz}, \mathrm{CD}_{3} \mathrm{OD}\right): \delta 7.54-7.50$ (m, 4H), 7.38-7.22 (m, 6H), $6.97(\mathrm{~m}, 2 \mathrm{H}), 6.90-6.80(\mathrm{~m}, 1 \mathrm{H}), 6.74-6.64(\mathrm{dd}, 1 \mathrm{H}), 6.53-6.50(\mathrm{~m}, 1 \mathrm{H}) 4.78$ (s, 1H), 4.65-4.55 (d, 1H) 4.30-4.20 (d, 1H) 4.04-4.15 (s, 2H), 3.80-3.60 (m, 6H), 3.50 (s, 2H), 3.3-2.7 (s, 12H) $2.15(\mathrm{~s}, 1 \mathrm{H})$; MS (MALDI-TOF) $\mathrm{m} / \mathrm{z} 644.78(\mathrm{M}+\mathrm{H})^{+}$, calcd for $\mathrm{C}_{39} \mathrm{H}_{54} \mathrm{~N}_{8} \mathrm{O}_{6}$ 644.84. The Co(III) complex of 1 was obtained by determination of the amount of Cyc portion by spectral titration with $\mathrm{CuCl}_{2}$ at $280 \mathrm{~nm}$ and $\mathrm{pH} 6.5$, by addition of an equivalent amount of $\mathrm{CoCl}_{2}$ to 1 , and by airoxidation of the complexed Co(II) ion according to literature (Castillo-Blum, S. E.; Sosa-Torres, M. E. Polyhedron 1995, 14, 223-229). 


\section{(6) Details of theoretical analysis}

1) references for programs and force filed:

JAGUAR 4.1 program: Ringnalda, M. N. Jaguar; Schroedinger Inc.: Portland, 1997.

AutoDock 3.0.5 program: Morris, G. M.; Goodsell, D. S.; Halliday, R. S.; Huey, R.; Hart, W. E.;

Belew, R. K.; Olson, A. J. J. Comput. Chem. 1998, 19, 1639-1662.

SANDER module of AMBER 7: Case, D. A.; Pearlman, D. A.; Caldwell, J. W.; Cheatham, T. E.,

III; Ross, W. S.; Simmerling, C.; Darden, T.; Merz, K. M., Jr.; Stanton, R. V.; Cheng, A.; Vincent, J. J.; Crowley, M.; Tsui, V.; Radmer, R.; Duan, Y.; Pitera, J.; Massova, I.; Seibel, G.

L.; Singh, U. C.; Weiner, P.; Kollman, P. A. AMBER 7, University of California, San Francisco, 2002.

Force field used for calculation with SANDER module of AMBER 7: Cornell, W. D.; Cieplak, P.; Bayly, C. I.; Gould, I. R.; Merz, K. M., Jr.; Ferguson, D. M.; Spellmeyer, D. C.; Fox, T.; Caldwell, J. W.; Kollman, P. A. J. Am. Chem. Soc. 1995, 117, 5179-5197.

\section{2) Results of molecular dynamics simulations}

The all-atom model for the PDF-Co(III)1 complex was neutralized by adding sodium ions and then was immersed in a rectangular box containing 9334 TIP3P water molecules. After 1000 cycles of energy minimization to remove the bad van der Waals contacts, we equilibrated the system beginning with 20 ps equilibration dynamics of the solvent molecules at $300 \mathrm{~K}$. The next step involved equilibration of the solute with a fixed configuration of the solvent molecules for 5 ps at 10, 50, 100, $150,200,250$, and $300 \mathrm{~K}$. Then, the equilibration dynamics of the entire system was performed at 300 $\mathrm{K}$ for $20 \mathrm{ps.}$ Following the equilibration procedure, 1.0 ns MD simulations were carried out with a periodic boundary condition in the NPT ensemble at $300 \mathrm{~K}$ using Berendsen temperature coupling and constant pressure $(1 \mathrm{~atm})$ with isotropic molecule-based scaling. The SHAKE algorithm, with a 
tolerance of $10^{-6}$, was applied to fix all bond lengths involving hydrogen atom. We used a time step of 2.0 fs and a nonbond-interaction cutoff radius of $12 \AA$; the trajectory was sampled every 0.2 ps (100 step intervals) for analysis. The results are summarized in Figure S1.

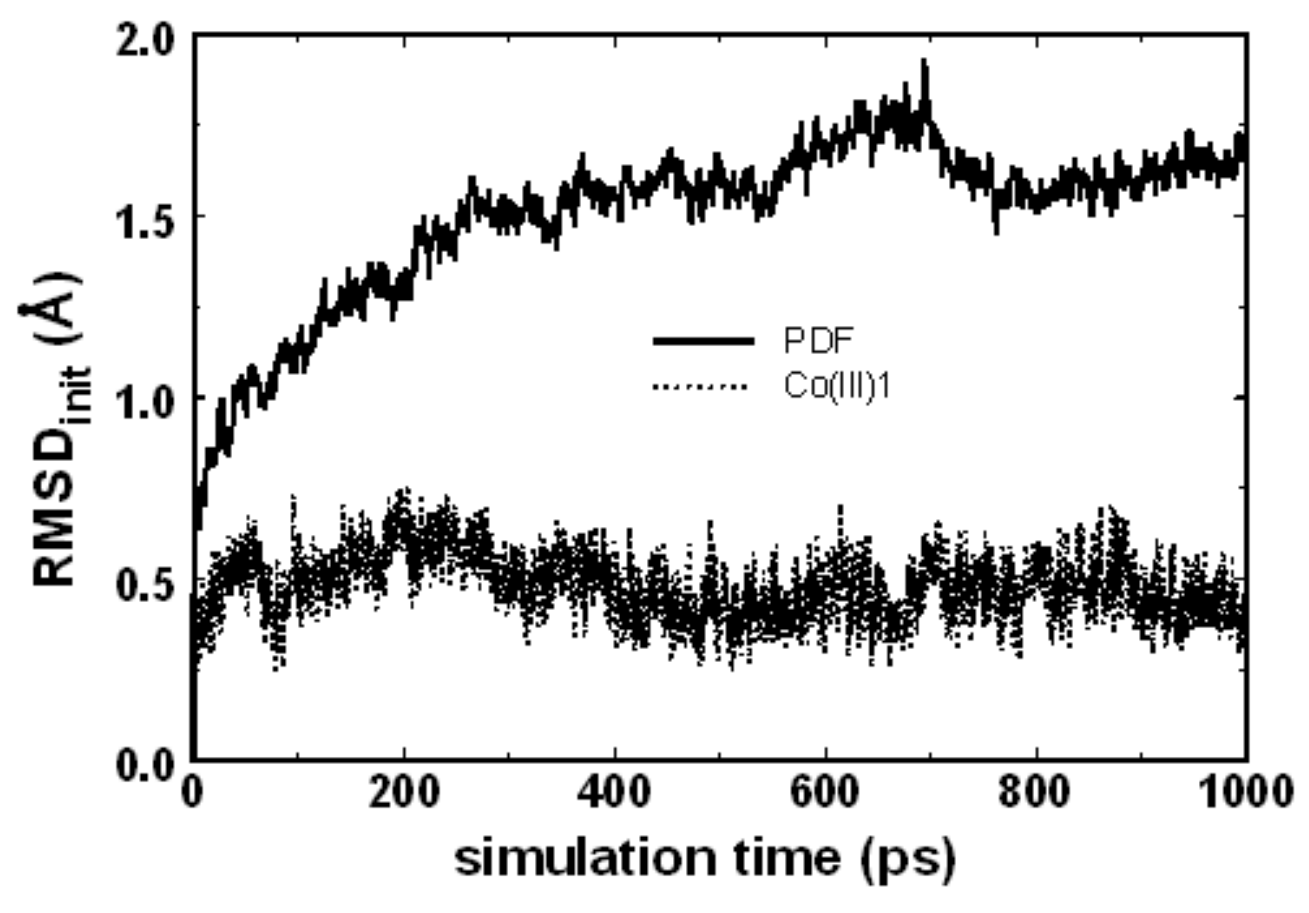

Figure S1. Comparative view of time evolutions of the root mean square deviations from the starting structure $\left(\mathrm{RMSD}_{\text {init }}\right)$ for $\mathrm{C}_{\alpha}$ atoms of PDF (solid line) and heavy atoms of Co(III)1 (dotted line). 


\section{(7) List of proteins tested with $\mathrm{Co}(\mathrm{III}) 1$}

1. human cyclin-dependent kinase 2

2. human kinase insert domain receptor

3. human farnesyl transferase

4. hepatitis $\mathrm{C}$ virus protease

5. YacM

6. $\mathrm{N}$-acetylglucosamine 1-phosphate uridyltransferase

7. UDP-N-acetylmuramoyl-L-alanine: D-glutamate ligase

8. non-structural protein 5B of hepatitis $\mathrm{C}$ virus

9. human protein-tyrosine phosphatase 1B

10. human retinoic $\mathrm{X}$ receptor $\alpha$

11. human peroxisome proliferator activated receptor $\alpha$

12. human peroxisome proliferator activated receptor $\gamma$

13. human liver $\mathrm{X}$ receptor $\alpha$

14. human liver $\mathrm{X}$ receptor $\beta$

15. human Caspase-8 